MENGENAL PUSAT KEBUDAYAAN MARITIM:

SUKU BAJO, SUKU BUGIS, SUKU BUTON, SUKU MANDAR

DI SEGITIGA EMAS NUSANTARA

Penulis: Afid Nurkholis

Email: afidnurkholis@gmail.com

\begin{abstract}
ABSTRAK
Indonesia adalah negara maritim begitulah orang-orang kerap menjukuli bangsa ini. Apabila hubungan deterministik dianggap berlaku, lingkungan tempat tinggal sekelompok manusia akan membentuk dan memengaruhi budaya yang ada. Setiap gugusan pulau hingga pesisir tentunya memiliki kondisi lingkungan yang unik. Lingkungan pertemuan antara Selat Makassar, Laut Jawa, dan Laut Flores merupakan salah satu pusat kebudayaan maritim Indonesia. Area tersebut dikenal sebahao segitiga emas nusantara. Enam suku yang memiliki kebudayaan berorientasi laut banyak beraktifitas di wilayah ini. Untuk lebih mengenali sukusuku berorientasi maritim di Indonesia, tulisan selanjutnya akan membahas mengenai pelautpelaut dari Bajo, Bugis, Buton, dan Mandar. Keempat suku ini merupakan yang paling memiliki catatan sejarah tertulis dari enam suku.
\end{abstract}

Katakunci: suku bajo, suku bugis, suku buton, suku mandar, kebudayaan maritim

Indonesia adalah negara maritim begitulah orang-orang kerap menjukuli bangsa ini. Indonesia merupakan negara yang memiliki kurang lebih 17.000 pulau dengan sekitar 4.000 diantaranya belum memiliki nama (BIG, n.d.). Ribuan pulau tersebut terdiri dari pulau besar hingga kecil yang dipisahkan oleh laut, selat, teluk dan perairan lainnya. Hal ini menjadikan banyak penduduk Indonesia memiliki hubungan erat dengan aspek kemaritiman dalam kesehariannya. Dahari (1996) menyatakan bahwa sekitar 60\% penduduk Indonesia tinggal di wilayah pesisir. Data tersebut menunjukkan bahwa lebih dari separuh penduduk Indonesia berinteraksi dengan lingkungan pesisir baik langsung maupun tidak.

Hubungan manusia dengan lingkungan sekitarnya dapat dikategorikan menjadi dua jenis, yaitu deterministik dan possibilistik (Fouberg dkk, 2012). Deterministik merupakan hubungan dimana keadaan lingkungan suatu tempat memengaruhi, mengontrol, bahkan menentukan perilaku suatu individu maupun kelompok. Possibilistik adalah hubungan dimana pada awalnya keadaan lingkungan memang membetuk perilaku suatu individu atau kelompok, namun seiring terjadinya interaksi, akulturasi budaya, dan perkembangan teknologi, manusia telah mampu mengatasi keterbatasan tersebut. Hubungan determinisitik telah banyak disangkal dan memang tidak relevan di abad 21 ini. Hal ini dapat dijelaskan secara sederhana, misalnya penduduk di daerah pegunungan yang notabenya tidak memiliki sumberdaya laut, saat ini dapat 
dan mudah saja menikmati ikan, kepiting, cumi-cumi, dan lobster. Adanya transportasi dan teknologi pengawetan telah mengamini bahwa hubungan possibilistik memang benar adanya.

Hubungan deterministik saat ini memang dianggap kurang relevan, meskipun demikian teori hubungan ini tidak sepenuhnya salah. Indonesia sebelum abad 18 mengalami masa dimana feodalisme mencapai puncak kejayaan sebelum dilemahkan oleh imperialisme Eropa. Dalam kurun waktu tersebut, hubungan deterministik benar adanya. Era tersebut melahirkan sejarah yang selalu dikenang oleh bangsa ini. Kerajaan Majapahit dengan armada lautnya mampu menyatukan Nusantara bahkan hingga Singapura. Selain itu, Indonesia yang memiliki laut luas mampu beradaptasi dengan lingkungannya. Hal ini dibuktikan dengan munculnya beberapa bandar/pelabuhan terkenal, seperti Gresik, Tuban, Batavia, dan tentunya Malaka.

Apabila hubungan deterministik dianggap berlaku, maka dapat dikatakan bahwa lingkungan tempat tinggal sekelompok manusia akan membentuk dan memmengaruhi budaya yang ada. Setiap gugusan pulau hingga pesisir tentunya memiliki kondisi lingkungan yang unik. Hal ini dapat dicontohkan dengan adanya pembagian garis Webber dan Wallace yang membagi flora dan fauna Indonesia menjadi Barat, Peralihan, dan Timur. Selain itu, Bemmelan (1949) menyatakan bahwa karakteristik lingkungan pesisir di Pulau Jawa bagian Utara dan Selatan memiliki perbedaan yang nyata. Indonesia memiliki ribuan pulau yang dipisahkan oleh berbagai jenis perairan, oleh karena itu dapat ditarik kesimpulan bahwa keragaman budaya maritim yang dimiliki pastilah sangat tinggi.

Lingkungan pertemuan antara Selat Makassar, Laut Jawa, dan Laut Flores merupakan salah satu pusat kebudayaan maritim Indonesia. Alimuddin (2013) menyebut wilayah ini sebagai Segitiga Emas Nusantara (Gambar 1). Tidak berlebihan kiranya apabila wilayah ini disetarakan dengan emas. Enam suku yang memiliki kebudayaan berorientasi laut banyak beraktifitas di wilayah ini, yaitu: Bajo, Bugis, Buton, Madura, Mandar, dan Makassar (Alimuddin, 2013). Lebih lanjut lagi, Segitiga Emas Nusantara memang layak disebut sebagai pusat kebudayaan maritim karena adanya empat hal seperti berikut:

1. Terjadinya akulturasi budaya antara keenam suku yang berorientasi maritim. Pertemuan ini tidak dapat dijumpai di wilayah lain Indonesia. Akulturasi budaya ini dapat dijumpai dalam hal pembuatan perahu, peralatan menangkap ikan, terminologi kebaharian, dan perdagangan.

2. Jalur paling ramai dalam kegiatan kemaritiman Indonesia dari dahulu hingga saat ini adalah wilayah Segitiga Emas Nusantara. 
3. Wilayah ini merupakan pertemuan antara laut dalam (Laut Flores dan Selat Makassar) dengan laut dangkal (Laut Jawa). Hal ini tentunya menjadikan adanya keunikan dan kebergaman dalam beradaptasi terhadap lingkungan tersebut.

4. Garis imajiner Wallace dan Webber berada di segitiga ini. Hal ini menyebabkan keragaman flora dan fauna khusunya bahari.

Untuk lebih mengenali suku-suku berorientasi maritim di Indonesia, tulisan selanjutnya akan membahas mengenai pelaut-pelaut dari Bajo, Bugis, Buton, dan Mandar. Keempat suku ini merupakan yang paling memiliki catatan sejarah tertulis dari enam suku yang disebutkan diatas.

\section{SUKU BAJO}

\subsection{Asal-Usul Suku Bajo}

Bajo merupakan satu-satunya suku yang tinggal sekaligus memiliki aktifitas utama di laut. Hal ini menjadikan Suku Bajo memiliki keunikan tersendiri dibandingkan kelima suku lain. Kelima suku lain tersebut beraktifitas di laut, namun tinggal di darat. Oleh sebab itu, Orang Bajo seringkali memiliki julukan sebagai orang laut, gipsi laut, atau pengembara laut (Suyuti, 2011). Saat ini Suku Bajo telah banyak yang tinggal di daratan akibat adanya berbagai macam perubahan (Gamsir, 2014).

Asal-usul Suku Bajo memiliki beragam versi dari mulai sekedar mitos hingga penelitian saintifik. Hal ini menjadikan asal Suku Bajo di Indonesia belum teridentifikasi secara jelas. Basri (2014) melakukan wawancara terhadap key person di Kepulauan Wakatobi bernama Bakri. Hasil wawancara menyatakan bahwa Suku Bajo berasal dari Johor, Malaysia. Cerita yang cukup melegenda adalah sang putri dari Johor melarikan diri ke Sulawesi hingga menikah dengan Pangeran Bugis. Beberapa rakyat Johor yang diperintahkan untuk mencari sang putri juga ikut menetap dan ditempatkan di wilayah yang bernama Bajoe.

Kisah mengenai sejarah Orang Bajo yang lain diutarakan oleh Tome Pires, seorang administrator Portugis yang tinggal di Malaka pada tahun 1515, dan orang Bajo yang tinggal di Sulawesi Tenggara (Suyuti, 2011). Menurut Tome Pires, orang Bajo berasal dari Makassar yang kemudian menjadi bajak laut. Aktifitas yang dilakukan suku ini selanjutnya adalah menyebar ke berbagai penjuru kepulauan, seperti Jawa Utara, Maluku, dan Banda. Sementara itu, Orang Bajo dari Sulawesi Tenggara menyatakan bahwa asal-usul mereka dari Kampung Ussu, Kecamatan Malili, Kabupaten Luwu, Sulawesi Selatan. Kata Bajo berasal dari bahasa Bugis ta'bajo-bajo yang berarti terbayang-bayang. Suatu ketika orang Bugis di Kampung Ussu melihat sekolompok orang di tengah laut secara tidak jelas dari kejauhan atau terbayangbayang (Nasruddin, 1998 dalam Suyuti, 2011). 


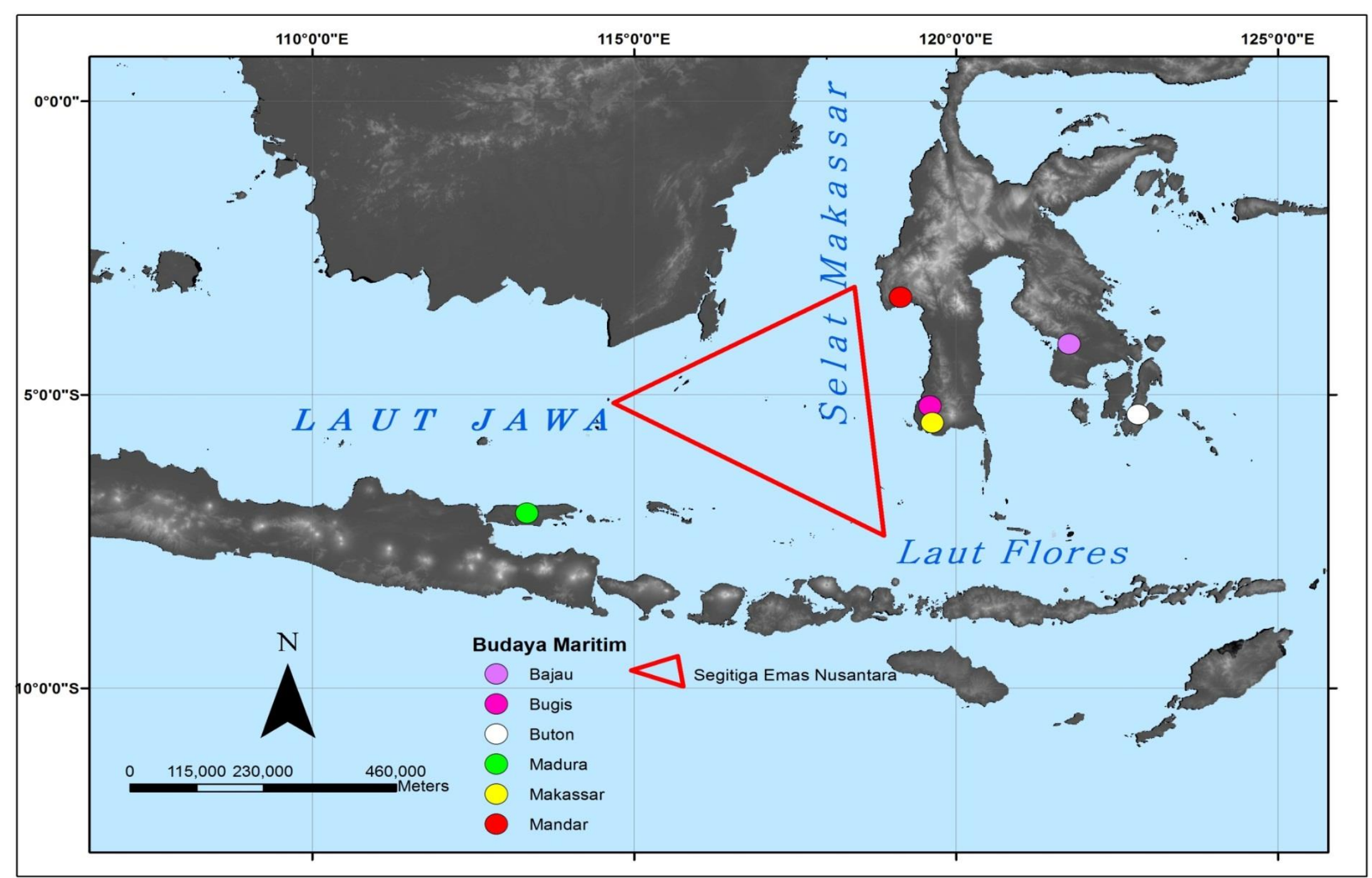

Gambar 1: Lokasi Segitiga Emas Nusantara 
Suku Bajo saat ini telah menyebar ke berbagai wilayah Indonesia (Suyuti, 2011). Suku ini tetap tinggal di wilayah pesisir meskipun tidak lagi di laut seperti dahulu kala. Di Pulau Sumatra suku ini dapat ditemui di sekitar pesisir Riau hingga Tanjung Jabung dekat Jambi. Di Pulau Sulawesi suku ini menyebar di beberapa kabupaten pada tiga provinsi, yaitu Sulawesi Utara, Sulawesi Selatan, dan Sulawesi Tenggara. Suku Bajo juga dapat ditemui di pantai utara dan timur Kalimantan, Kepulauan Maluku, sepanjang pantai utara Sumbawa, sepanjang pantai barat dan utara Flores, Pulau Babi, serta Kelupauan Alor.

\subsection{Ritual Duata: Cara Pengobatan Khas Suku Bajo}

Ritual Duata merupakan tradisi masyarakat Bajo di Kepulauan Wakatobi. Tradisi ini dilakukan untuk mengobati orang yang sakit keras dan tidak dapat disembuhkan dengan cara pengobatan biasa atau medis (Basri, 2014). Terminologi Duata memiliki arti dewa yang turun dari langit dan menjelma menjadi manusia untuk menyembuhkan penyakit (Wakatobicenter, 2015). Upacara ini dilakukan sewaktu-waktu apabila ada masyarakat yang mengalami sakit seperti dijelaskan diatas. Prosesi Ritual Duata dapat diuraikan menjadi enam prosesi yang beruruan (Basri, 2014), yaitu:

\section{a. Persiapan sarana material}

Sarana material untuk prosesi disiapkan oleh tuan rumah yang anggota keluarganya sakit. Prosesi dari awal hingga akhir upacara dipimpin oleh seorang sandro atau dalam bahasa lain dukun. Material yang disiapkan terdiri dari bermacam sesajian, pakaian khusus, dan tetabuhan.

\section{b. Memeriksa tubuh pasien}

Pemeriksaan pasien dilakukan oleh sandro dengan cara berkomunikasi dengan roh. Mantra digunakan sebagai perantara dalam komunikasi dengan roh. Mantra yang digunakan terdiri dari tiga jenis yang dibacakan berurutan. Hal ini dilakukan karena penyakit yang diderita diakibatkan oleh masuknya roh kedalam tubuh pasein. Roh tersebut terdiri dari dua jenis, yaitu roh darat dan laut.

\section{c. Prosesi penyiraman pertama}

Proses penyiraman pertama dilakukan mulai pukul 18.00. Air yang digunakan telah diberi mantra tertentu oleh sandro (Gambar 1.1). Pasien yang telah selesai dimandikan kemudian menggunakan sarung. Setelah itu, pasien dibiarkan beristirahat dengan larangan tidak boleh keluar rumah.

\section{d. Prosesi penyiraman kedua}

Prosesi ini dilakukan pada pukul 04.00. Ritual dimulai dengan memandikan pasien seperti tahap sebelumnya. Perbedaan pada tahap ini adalah digunakannya buah mayah untuk 
mengalirkan air keseluruh tubuh pasien. Ritual pemandian pertama dan kedua ini berlangsung selama tiga hari berturut-turut.

Tetabuhan gendang merupakan hal yang wajib ada selama prosesi penyiraman pertama dan kedua berlangsung (Gambar 1.2). Fungsi bunyi tetabuhan ini adalah untuk memberi semangat pasien. Selain itu, bunyi tetabuhan dipercaya mempunyai kekuatan magis yang dapat membantu menyembuhkan penyakit.

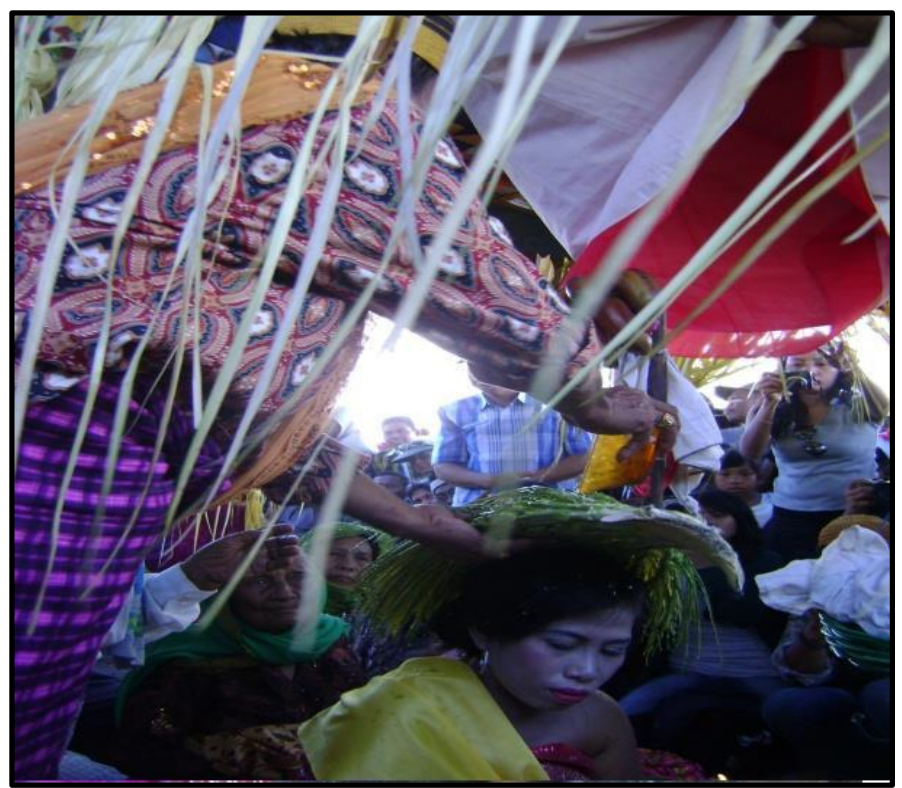

Gambar 1.1. Proses penyiraman (Basri, 2014)

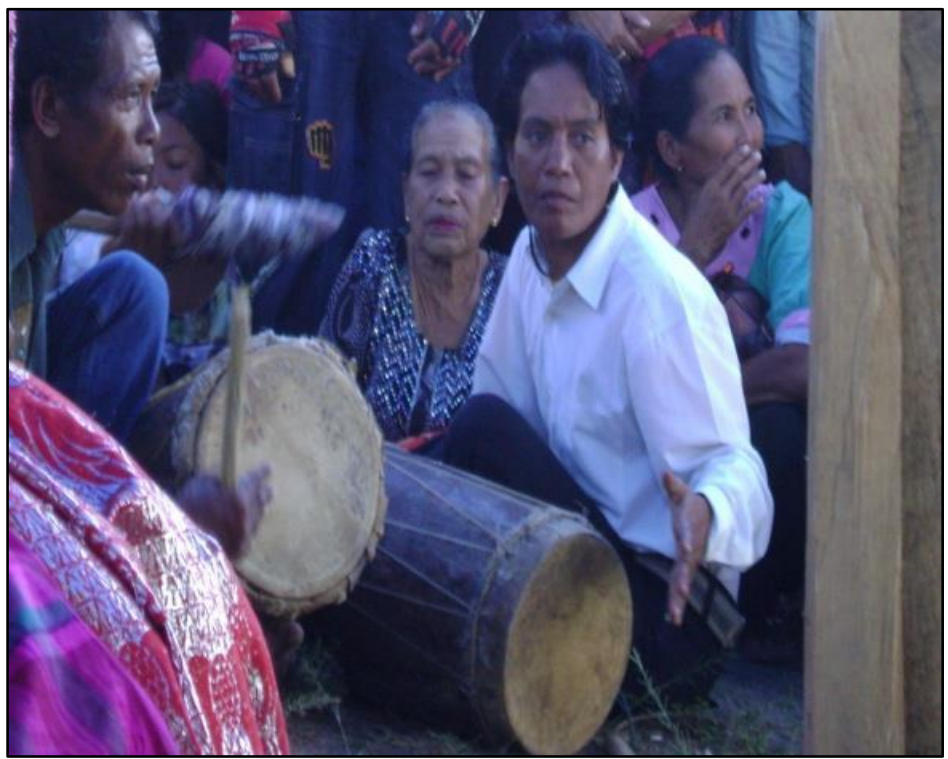

Gambar 1.2. Tetabuhan gendang (Basri, 2014)

\section{f. Permohonana keselamatan dan kesembuhan}

Prosesi terakhir dilakukan dengan cara membaca mantra. Mantra ini digunakan untuk memohon keselamatan dan kesembuhan terhadap Tuhan, roh-roh penguasa laut, dan para leluhur. Mantra tersebut terdiri dari empat jenis yang dibacakan secara berurutan. 


\subsection{Perubahan Kehidupan Suku Bajo}

Suku Bajo yang sebelumnya dikenal beraktifitas dan tinggal di laut saat ini telah mengalami perubahan. Adanya perkembangan teknologi, desakan ekonomi, pengaruh budaya suku lain, dan intervensi pemerintah adalah sebab utama perubahan ini (Gamsir, 2014). Perubahan yang dialami suku Bajo terjadi secara bertahap. Suyuti (2011) mengidentifikasi lima periode perubahan tersebut, yaitu:

\section{a. Mitos Sawerigading: Munculnya Orang Bajo}

Mitos ini berawal dari Sawerigading yang berasal dari Ussu Cerekang, Kabupaten Luwu, Sulawesi Selatan. Sawiragading menebang pohon besar bernama Walenrangnge. Ketika pohon tumbang, telur burung yang bersarang di pohon berjatuhan. Hal ini menimbulkan banjir telur. Banjir ini menghanyutkan masyarakat Ussu beserta rumah-rumahnya ke lautan. Rumah-rumah yang mengapung di laut ini selanjutnya disebut Bido. Masyarakat Bajo yang hanyut terbawa anging yang menyebabkan mereka tersebar dimana-mana.

\section{b. Nomaden: Kehidupan di Atas Bido}

Suku Bajo tinggal dan beraktifitas di laut dari generasi ke generasi. Mereka mulai menganggap laut merupakan karunia dari Tuhan YME yang diberikan kepada nenek moyangnya. Suku Bajo mulai mengarungi lautan hingga ke Asia Tenggara. Ciri utama periode ini adalah segala aktifitas utama dilakukan pada Bido secara berpindah-pindah di lautan. Daratan hanyalah tempat perlindungan sementara, semisal ketika ada badai, dan mendapatkan kebutuhan air tawar.

Periode ini juga ditandai dengan adanya aktifitas dengan orang Bugis terutama dalam hal ekonomi, yakni sistem barter. Kehidupan Suku Bajo yang berada di laut membuatnya harus menjalin hubungan dengan orang darat untuk memenuhi kebutuhannya, seperti peralaan melaut, beras, tembakau, dan gula. Interaksi dengan suku Bugis ini nantinya berjalan semakin intensif yang menjadi salah satu penyebab berubahnya budaya Suku Bajo.

\section{c. Masa Transisi: Beranjak ke Pantai}

Periode transisi dicirikan dengan berubahnya pola hidup berpindah Suku Bajo menjadi menetap di pantai. Salah satu tempat bermukim awal suku ini adalah di Pantai Sulaho. Tempat ini dipilih karena karakteristiknya yang sesuai untuk menetap, yaitu lokasi dikelilingi gunung yang menjadikannya terpencil, topografi pantai yang landai, serta adanya tanjung yang mengelilinginya. Salah satu contoh bentuk rumah Suku Bajo ketika bermukim di pesisir dapat dilihat pada Gambar 1.3

Periode ini juga ditandai dengan mulai intensifnya suku Bajo menggunakan bahasa Bugis. Pasukan pemberontak DI/TII yang bersembunyi di wilayah Sulaho menjadikan Suku 
Bugis banyak melakukan interaksi dengan Suku Bajo. Pondok-pondok agama yang dibuka oleh DI/TII selanjutnya menjadikan hubungan ini semakin erat dan tentunya memengaruhi budaya Bajo.

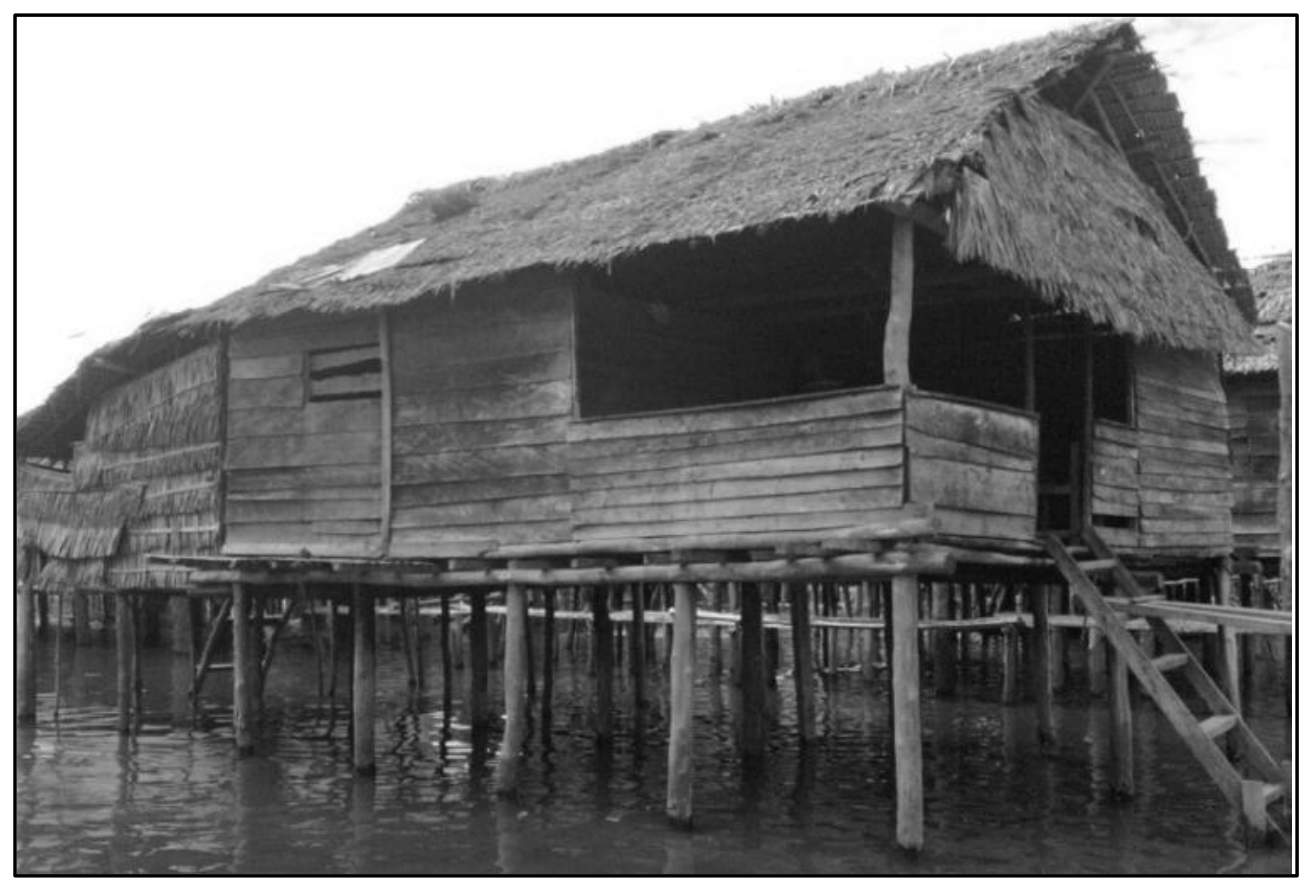

Gambar 1.3. Rumah panggung Suku Bajo (Rifai, 2010)

\section{d. Di Darat: Berdirinya Permukiman}

Tahun 1972 merupakan awal dimulainya permukiman di darat oleh seluruh anggota suku Bajo di Sulaho. Selain bermukim di darat, ciri utama periode ini adalah adanya kebutuhan sarana produksi dan transportasi, Hal ini dikarenakan Suku Bajo sebagai suku yang tinggal di darat namun masih beraktifitas di laut. Suku Bajo semakin memiliki hubungan erat atau dalam kata lain bergantung terhadap Suku Bugis. Beragam jenis perahu mulai digunakan Suku Bajo untuk melaut. Hal ini mulai menimbulkan adanya kelas sosial pada masyarakat ini, sehingga Orang Bajo yang memiliki keterbatasan alat produksi mulai beralih profesi menjadi petani.

\section{e. Intervensi Pemerintah: Sistem Permukiman Sosial (SPS)}

Tinggalnya Suku Bajo di daratan menjadikannya mulai merasakan berbagai program dari pemerintah. Program tersebut dimulai dengan adanya pembangunan 85 unit rumah semi permanen pada tahun 1996 di Kampung Sulaho. Program ini disertai dengan jaminan hidup berupa bantuan pangan selama lima tahun dan infrastuktur kehidupan masyarakat. Adanya program pemerintah tersebut tentunya telah jauh merubah tatanan budaya Suku Bajo. Hal yang paling menyolok adalah mulai ditinggalkannya dukun, mortalitas menurun, kesehatan masyarakat meningkat, dan status sosial mulai diperhatikan. 


\section{SUKU MANDAR}

\subsection{Asal-Usul Suku Mandar}

Mandar merupakan salah satu suku berbudaya maritim yang berasal dari Provinsi Sulawesi Barat (saat ini). Lahirnya Suku Mandar dapat ditelusuri pada abad 16. Menurut Alimuddin (2013) tujuh kerajaan kecil bersepakat membentuk federasi pada akhir abad 16. Nama federasi ini adalah Pitu Baqbana Binaga yang berarti tujuh kerajaan di muara sungai. Selanjutnya, federasi tersebut bergabung dengan federasi tujuh kerajaan dari pegunuungan. Nama baru federasi ini adalah Pitu Baqbana Binanga dan Pitu Ulunna Salu yang artinya tujuh kerajaan di muara sungai dan tujuh kerajaan di hulu sungai.

Penamaan Mandar dari segi bahasa memiliki dua tafsiran (Yahya, 2013). Pertama, Mandar berasal dari dua kata bahasa Hindu yaitu man dan dhar yang ketika digabung membentuk kata dharman, berarti mempunyai penduduk. Kedua, Mandar merujuk kepada aliran Sungai Mandar yang berhulu di Kecamatan Malunda (Kabupaten Majene) dan bermuara di Kota Tinambung (Kabupaten Polewali Mandar). Arti kata Mandar yang kedua menunjukkan keterkaitan dengan sejarah terbentuknya masyarakat Mandar seperti yang dijelaskan sebelumnya.

\subsection{Lingkungan Suku Mandar}

Menurut Alimuddin (2013), suku Mandar memiliki budaya bahari karena tanah tempat mereka berasal tidak cocok sebagai perairan. Hal ini dapat dijelaskan melalui interpretasi Peta Geologi Lembar Mamuju. Sulawesi Barat yang merupakan tempat asal Suku Mandar memiliki tiga formasi geologi dominan yaitu Tma (Batuan Gunungapi Adang), Tmm (Formasi Mamuju), TMMT (Anggota Tapalang, Formasi Mamuju). Formasi Tma berasal dari sisa-sisa gunungapi tersier. Formasi Tmm dan TMMT berasal dari endapan terumbu yang terangkat membentuk Batugamping. Keadaan geologi ini menjadikan tanah yang berada di wilayah ini cenderung tipis dan tidak subur. Oleh karena itu, tidak mengherankan apabila Suku Mandar memilih memiliki orientasi bahari.

Lingkungan asal Suku Mandar memang mengharuskan mereka berinovasi agar dapat tetap hidup. Karakteristik laut merupakan pembeda antara suku Mandar dengan kelima suku lain yang dibahas dalam tulisan ini. Mandar merupakan satu-satunya suku yang langsung dihadapkan dengan laut dalam (Selat Makassar) (Alimuddin, 2013). Suku Bugis dan Makassar memiliki Kepulauan Spermonde, Taka Bonerate, dan Sembilan di hadapannya. Suku Butun memiliki Kepulauan Wakatobi, Suku Madura memiliki Kepulauan Kangean, dan Suku Bajo sedari awal telah tersebar di berbagai pulau kecil seperti telah dijelaskan di bab sebelumnya. 


\subsection{Budaya}

Christian Pelras dalam buku The Bugis (1996) mengatakan bahwa pelaut ulung yang sebenarnya adalah suku Mandar (Alimuddin, 2013). Pendapat tersebut seakan memiliki kontradiksi jika melihat bahwa masyarakat Mandar tidak memiliki armada perang hebat, benteng besar kokoh, bukan juga pedagang yang handal. Keulungan yang dimaksud Pelras diatas adalah keulungan bahari suku Mandar dalam beradaptasi terhadap lingkungan sekitarnya. Adaptasi tersebut mampu menghasilkan teknologi perikanan yang diadaptasi masyarakat bahari lain, yaitu rumpon, Perahu Sandeq, dan menangkap ikan sambil menghanyut di tengah laut.

\section{a. Perahu Sandeq}

Perahu Sandeq merupakan perahu karya terbaik khas Mandar. Menurut (Alimuddin, 2013), perahu ini adalah yang tercepeat di seluruh Austronesia dalam kategori perahu tak bermesin (Gambar 2.1). Sandeq seolah berlari apabila dibandingkan dengan perahu tanpa bermesin lain yang diibaratakan berjalan. Perahu Sandeq lahir pada sekitar dasawarsa 1930 di Kampung Pambusuang, Sulawesi Barat. Secara bahasa, kata sandeq merupakan bahasa Mandar yang berarti runcing. Hal ini mengacu pada bentuk perahu yang berhaluan tajam.

Pembuatan Perahu Sandeq memiliki ciri khas berupa adanya ritual tertentu (Amrullah, 2015). Hal ini dikarenakan Perahu Sandeq tidak hanya dianggap sebagai alat melaut saja melainkan benda hidup yang menemani mereka belayar. Ritual yang dilakukan dalam pembuatan Perahu Sandeq dapat digolongkan menjadi tiga, yaitu awal pembuatan perahu, proses pembuatan perahu, dan setelalah pembuatan perahu (Amrullah, 2015). Penjelasan mengenai setiap ritual tersebut dapat dilihat pada Tabel 2.1.

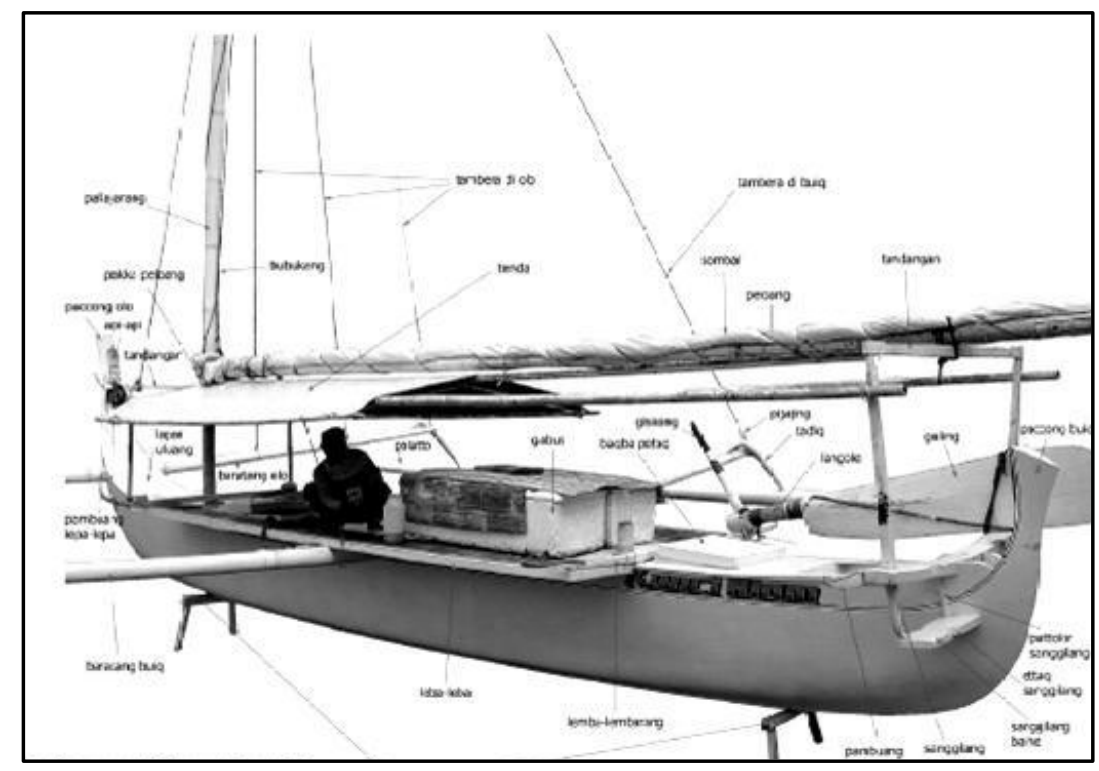

Gambar 2.1. Konstruksi Perahu Sandeq (Alimuddin, 2013) 
Tabel 2.1. Ritual Tahap Pembuatan Perahu Sandeq (Amrullah, 2015)

\begin{tabular}{|c|c|c|c|}
\hline No & $\begin{array}{c}\text { Tahap Pembuatan } \\
\text { Perahu }\end{array}$ & Ritual & Kegiatan \\
\hline 1 & Awal Pembuatan & Mambaca-baca & $\begin{array}{l}\text { Ritual memohon doa untuk } \\
\text { keselamatan selama proses } \\
\text { pembuatan perahu. }\end{array}$ \\
\hline 2 & Proses Pembuatan & Mattobo & $\begin{array}{c}\text { Pemasangan papan pertama } \\
\text { dianggap menentukan keberhasilan } \\
\text { perahu, sehingga harus dilakukan } \\
\text { sendiri oleh kepala tukang dengan } \\
\text { rangkaian mantra dan ussul tertentu. }\end{array}$ \\
\hline & & Memasang Pallayarang & $\begin{array}{c}\text { Pemasangan tiang layar sebagai } \\
\text { penggerak utama perahu diiringi } \\
\text { dengan ussul sebagai pengaharapan } \\
\text { kuatnya tiang layar yang digunakan }\end{array}$ \\
\hline \multirow{4}{*}{3} & \multirow{4}{*}{ Setelah Pembuatan } & Mapposiq & $\begin{array}{l}\text { Pengisian jiwa perahu dilakukan } \\
\text { dengan membuat lubang kecil pada } \\
\text { dasar perahu bagian tengah. }\end{array}$ \\
\hline & & Kuliwa & $\begin{array}{l}\text { Acara syukuran peresmian perahu } \\
\text { sebagai tanda sandeq siap digunakan }\end{array}$ \\
\hline & & Makkotaq sanggilang & $\begin{array}{c}\text { Pembuatan lubang kemudi yang } \\
\text { dilakukan oleh kepala tukang }\end{array}$ \\
\hline & & Peluncuran perahu & $\begin{array}{l}\text { Mempertemukan perahu dengan laut } \\
\text { untuk pertama kalinya. }\end{array}$ \\
\hline
\end{tabular}

\section{b. Festival Sandeq Race}

Festival Sandeq Race merupakan acara perlombaan tahunan yang digagas oleh ilmuwan budaya maritim bernama Horst. Festival ini memiliki rute dari Mamuju hingga mencapai akhir di Makassar. Perlombaan tahunan ini sejatinya menjadi penyelamat kepunahan Perahu Sandeq yang mulai digantikan perahu bermesin (Alimuddin, 2013). Selain itu, kegiatan ini juga mampu mengangkat pamor pariwisata Sulawesi karena masuk dalam kalender pariwisata internasional. Meskipun demikian, Alimuddin (2004) menyatakan bahwa ajang ini hanya hanya mejadikan para pelaut sebagai komoditas dan mencari muka terhadap pejabat diatasnya. Hal ini dibuktikan 
dengan kurangnya informasi dan apresiai seperti ketentuan lomba, jumlah hadiah , tanggal mulai hingga tidak adanya pengobatan dan air minum.

\section{c. Rumpon}

. Rumpon merupakan alat bantu penangkapan ikan yang merupakan mahakarya Suku Mandar selain Perahu Sandeq (Alimuddin, 2004; Alimuddin, 2013). Pujian tersebut tidak berlebihan mengingat penggunaan rumpon saat ini yang telah mendunia. Rumpon pada dasarnya merupakan alat bantu penangkapan ikan dengan cara kerja memikat ikan yang berada disekitarnya, sehingga ikan mudah ditangkap (Monintja, 1995 dalam Zulkarnain, 2002). Menurut Alimuddin (2013), rumpon terdiri dari empat komponen utama, yaitu batu (pemberat), tali, pemikat ikan, dan pelampung (Gambar 2.2). Tertariknya ikan oleh rumpon dapat dijelaskan oleh empat hal (Subani, 1989 dalam Siahaan, 2005). rumpon digunakan sebagai tempat berteduh, tempat mencari makan, substrat meletakkan telur, dan tempat berlindung dari pemangsa.

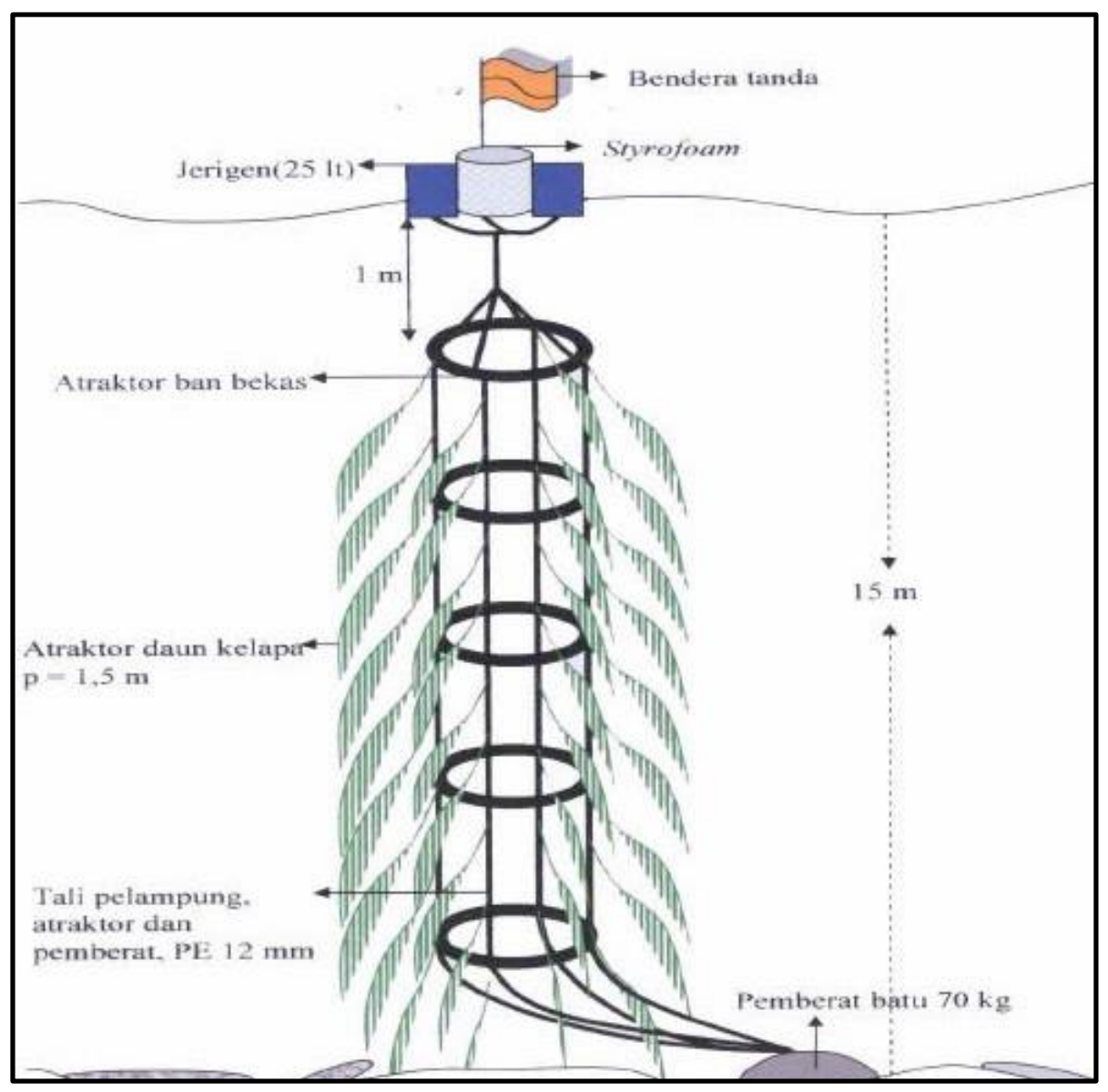

Gambar 2.2. Konstruksi Rumpon (Siahaan 2011)

Penggunaan rumpon yang semakin banyak di Indonesia membuat pemerintah megaturnya dalam Keputusan Menteri Kelautan dan Perikanan Nomor KEP.30/MEN/2004 
tentang Pemasangan dan Pemanfaatan Rumpon. Peraturan tersebut mengatur kewenangan pemberian izin pemasangan rumpon sebagai berikut:

1. Perairan dengan jarak $2-4$ mil dari laut pemberi izin adalah walikota atau bupati dengan masa berlaku 2 tahun.

2. Perairan dengan jarak $4-12$ mil dari laut pemberi izin adalah gubernur dengan masa berlaku 2 tahun.

3. Perairan dengan jarak besar dari 12 mil dan ZEEI pemberi izin adalah Ditjen Perikanan Tangkap dengan masa berlaku 2 tahun.

Sementara itu, syarat pemasangan rumpon berdasarkan peraturan diatas harus memperhatikan hal-hal berikut:

1. Tidak mengganggu alur pelayaran

2. Jarak antar rumpon minimal $10 \mathrm{mil}$

3. Tidak memasanag rumpon secara zig-zag atau yang memagari.

4. Pemasang rumpon wajib memasang tanda pengenal, membongkar yang sudah tidak dimanfaatkan, menyanpaikan laporan kepada pemberi izin selama 6 bulan sekali

\section{SUKU BUGIS}

\subsection{Asal-Usul Suku Bugis}

Suku Bugis menjadi bagian penting dalam budaya bahari Nusantara. Menurut Pelras (1996), orang Bugis merupakan pedagang antar pulau yang disegani terutama ketika sebelum abad 19. Kuatnya pengaruh Suku Bugis dapat dibuktikan dengan banyaknya nama "Kampung Bugis" di Indonesia, bahkan kampung tersebut ada di Singapura (Alimuddin, 2013). Lebih lanjut lagi, ketenaran Suku Bugis menjadikan banyak orang menggeneralisir seluruh suku yang ada di Sulawesi sebagai orang Bugis.

Bugis merupakan suku yang berasal dari daerah Sulawesi Selatan. Orang Bugis berasal dari migrasi pertama orang-orang Asia (terutama Cina) menuju kepulauan Austronesia (Pelras, 1996). Beberapa kelompok migrasi tersebut mendiami wilayah Sulawesi Selatan. Adanya akulturasi budaya antara Cina, Melayu, India, dan terutama Islam telah membentuk Suku Bugis yang dicirakan dengan bahasa dan adat-istiadat khas.

Komunitas Bugis di Sulawesi Selatan selanjutnya mengalami perkembangan menjadi beberapa kerajaan (Caldwell, 1995). Kerajaan Bugis klasik pada masa itu diantaranya adalah Luwu, Bone, Wajo, Soppeng, Suppa, Sawitto, Sidenreng, dan Rappang. Adanya banyak kerajaan tersebut menjadikan konflik peperangan menjadi kerap terjadi. Hal ini menjadi salah satu penyebab awal mula banyaknya orang Bugis yang menyebar ketempat lain. Setelah era 
kerajaan ini, kolonialisme mulai memonopoli perdagangan di Sulawesi Selatan yang selanjutnya menjadi penyebab kedua menyebarnya Suku Bugis.

\subsection{Keulungan Pedagang Bugis}

Suku Bugis menempati wilayah yang tergolong subur (Caldwell, 1995). Orang Bugis pertama kali menetap di wilayah sekitar pesisir Teluk Mandar hingga ke Makassar. Topografi wilayah ini tergolong datar dengan material tanah alluvial. Hal tersebut menjadikan aktifitas pertanian dan nelayan merupakan mata pencaharian utama suku Bugis pada masa sebelum abad 19. Keterangan tersebut juga menjadi penjelas mengenai barang dagangan utama Suku Bugis yang berupa beras.

Keulungan Suku Bugis dalam berdagang utamanya disebabkan oleh peran mereka dalam perdagangan di pelabuhan Malaka (Hussin, 2008). Pedagang Bugis mampu membuat pusat perdagangan baru di Riau setelah Malaka dikuasai oleh Belanda pada 1874. Pusat perdagangan baru tersebut telah mengubah sejarah dan struktur pemerintahan kerajaan Melayu-Johor.

Cerita heroik lain adalah ketika pedagang Bugis berhasil menjadikan Pulau Pinang berkembang setelah dibuka Inggris pada tahun 1786 (Hussin, 2008). Pulau Pinang memiliki keterbatasan sumber daya alam yang menjadikannya tidak memiliki bahan mentah untuk diperdagangkan. Pedagang Bugis membawa berbagai macam hasil pertanian dari tanah Sulawesi, seperti rempah, beras, lada hitam, hasil laut, dan galian. Datangnya pedagang Bugis ke pulau ini berhasil menarik pedagang-pedagang lain dari Cina dan India untuk meramaikan Pulau Pinang.

Hussin (2008) menyatakan bahwa kesuksesan pedagang Bugis tidak dapat dilepaskan dari konsep yang telah memberi mereka kekuatan, yaitu berupa siri dan pese. Kedua konsep tersebut pula yang menjadikan pedagang Bugis terkenal pandai dan jujur (Pelras, 1996). Siri merupakan konsep yang berkaitan dengan kekuatan jati diri dan unsur malu. Orang Bugis seringkali memberi peringatan bahwa "lebih baik mati demi mempertahankan siri dibandingkan dengan kehidupan yang tidak memiliki siri”. Konsep siri menjadikan setiap pedagang Bugis selalu berusaha jujur dan menjaga integritas mereka. Konsep pesse merupakan suatu kepercayaan adanya kesatuan rohani pada individu (Mustafa, 2003). Hussin (2008) menterjemahkan definisi pesse sebagai kekuatan ikatan persaudaraan yang sangat penting demi membela dan memperkokoh komuniti Bugis. Konsep ini juga memberi makna pentingnya tradisi gotong royong.

Sifat kepribadian orang Bugis juga dipengaruhi oleh cerita legenda sejarah I La Galigo (Pelras, 1996). Tokoh Sawerigading dikisahkan sebagai raja dari Bugis yang memiliki sifat teguh pendirian, berani, jujur, dan pintar. Cerita tersebut sangat terkenal diantara orang Bugis, 
sehingga dapat dikatakan keempat sifat Sawerigading merasuk kesetiap kepribadian pedagang Bugis.

\subsection{Kesalahpahaman Kapal Pinisi}

Pinisi merupakan kapal yang menjadi alat transportasi utama perdagangan laut di Nusantara pada abad 19 (Gambar 3.1). Kapal Pinisi oleh beberapa pihak seringkali disalahtafsirkan sebagai produk asli budaya Bugis (Pelras, 1996). Hal ini tentu saja keliru apabila melihat asal-usul Suku Bugis. Orang bugis memang merupakan pedagang yang ulung, namun mereka hanya menggunakan Pinisi untuk mengarungi pulau-pulau. Keterkenalan Suku Bugis menjadikannya ikut dicap sebagai penemu Kapal Pinisi. Kapal Pinisi sebenarnya dibuat oleh orang-oranag berbahasa Konjo yang merupakan sub-group dari suku Makassar (Alimuddin, 2013).

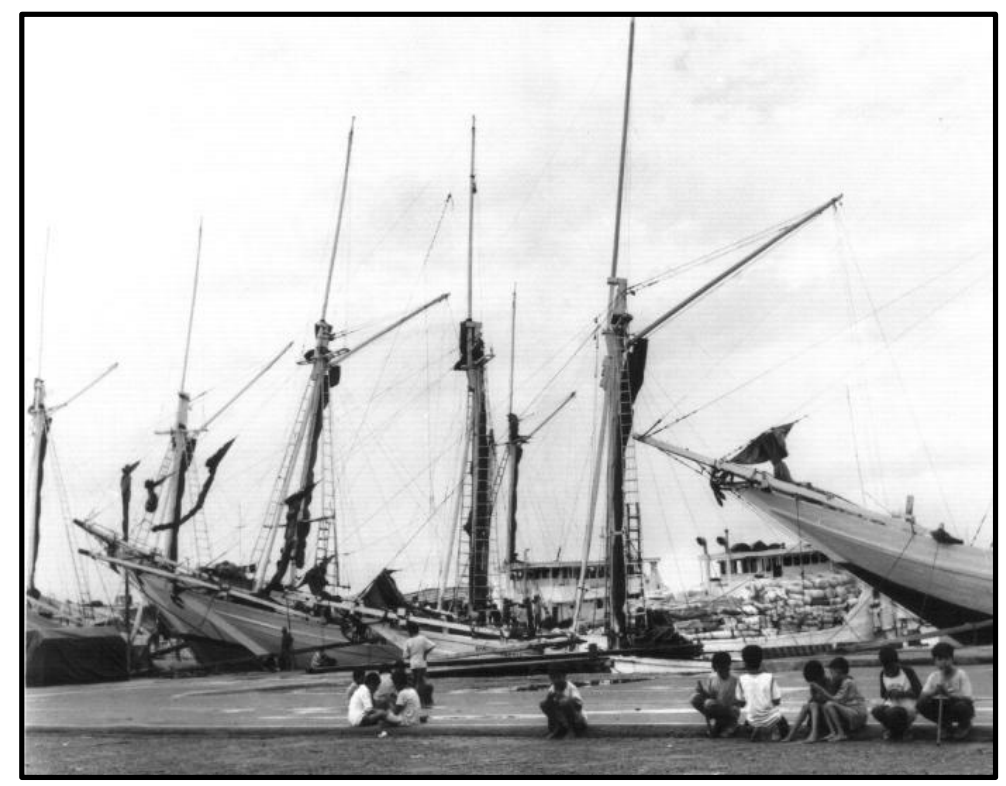

Gambar 3.1. Kapal Pinisi (Obrowsk, 1994)

\section{MASYARAKAT BUTON}

\subsection{Asal-Usul Masyarakat Buton}

Nama Buton sebagai salah satu pusat budaya maritim tidak merujuk terhadap suatu suku tertentu seperti Bajo, Mandar, Bugis, dan Makassar. Buton pasa zaman dahulu merupakan suatu wilayah kesulanan yang bernama Wolio (Zuhdi dkk, 2009). Kesultanan Wolio berdiri pada abad ke 14 dan berakhir pada tahun 1960. Wilayah kekuasaan ini dahulu kala mencaup Pulau Kabaena, Pulau Muna, Pulau Tiworo, Pulau Buton, dan Kepulauan Tukang Besi (Wakatobi). Wilayah tersebut saat ini secara administrative merupakan bagian dari Provinsi Sulawesi Tenggara.

Wilayah Kesultanan Buton merupakan kepulauan dimana wilayah lautnya lebih luas daripada daratan. Interpretasi Peta Geologi Lembar Buton menunjukkan bahwa litologi 
wilayah ini tersusun oleh material endapan laut yang mengalami pengangkatan membentuk pulau, seperti sedimen pasir, lanau, lempung dan endapan koral yang membentuk batugamping. Luasan batugamping lebih mendominasi di kepulauan ini. Hal tersebut mengakibatkan tanah yang ada cenderung tidak cocok sebagai area pertanian. Kombinasi antara lautan yang membentang luas dan tanah yang tidak subur mendorong masyarakat Buton berorientasi maritim (Zuhdi dkk, 2009).

\subsection{Kepulauan Tukang Besi: Identitas Maritim Buton Sebenarnya}

Buton yang terdiri dari banyak pulau tidak otomatis menjadikan setiap wilayahnya memiliki pelaut ulung yang selama ini disegani. Hadara (2006) menyatakan bahwa para pelaut Buton yang selama ini disegani pada dasarnya adalah pelaut-pelaut yang beasal dari Kepulauan Tukang Besi. Hal tersebut dikarenakan pelaut Kepulauan Tukang Besi memiliki tiga keunggulan dan dua peran. Tiga keunggulan pelaut ini yaitu memiliki kemahiran membuat perahu layar tradisional, keberanian berlayar di alam bebas, dan kemampuan menerima perkembangan teknologi pelayaran. Sementara itu, dua peran yang dimaksud adalah ikut menuebarluaskan Isalam dan kebudayaan dalam pelayaran serta membantu perjuangan mencapai dan mempertahankan kemerdekaan Indoenesia.

Terminologi tukang besi berasal dari dua cerita pada zaman pendudukan Belanda (Hadara, 2006). Pertama, nama tersebut berasal dari seorang Belanda bernama Hoger yang melihat penduduk di Pulau Binongko membuat berbagai peralatan dari besi. Kedua, istilah Tukang Besi berasal dari Raja Hitu, seorang tengkulak besi, yang para pengikutnya memberontak dan membunuh para sedadu Belanda di Pulau Wangi-Wangi ketika diasingkan dari Batavia.

Nama Tukang Besi secara resmi telah berganti menjadi Wakatobi pada tahun 2003. Pergantian tersebut dilakukan seiring pemekaran Kepulauan Wakatobi menjadi kabupaten yang terpisah dari Buton. Istilah Wakatobi merupakan aknronim dari nama-nama pulau besar yang ada, yaitu Pulau Wangi-Wangi, Pulau Kaledupam Pulau Tomia, dan Pulau Binongko (Gambar 4.1). Sebenarya, gugusan kepulauan ini terdiri atas 33 pulau dimana 25 pulau belum dihuni manusia (Zuhdi dkk, 2009).

\subsection{Penjelajahan Pelaut Tukang Besi}

Penjelajahan para Pelaut Tukang Besi tidak hanya sebatas wilayah Nusantara. Mereka juga telah berlayar ke beberapa negara seperti Singapura, Malaysia, Deli, Filipina Selatan, Filipina Timur Australia Utara, dan Pakistan (Hadara, 2006). Penjelajahan ini mereka lakukan menggunakan perahu tradisional bernama lambo (gambar 4.2). Beberapa penjelajahan pelaut Tukang Besi yang membuat mereka disegani dapat dilihat pada Tabel 4.1. 
Perahu lambo merupakan hasil karya asli masyarakat Buton (Zuhdi dkk, 2009). Meskipun demikian, pembuatan lambo tetap menyerap pengetahuan dari barat. Perahu ini memiliki keunikan berupa penggunaan layar nade yang merupakan produk barat. Perahu Lambo mampu mengangkut barang hingga 300 ton. Lambo juga digadang-gadang menjadi pesaing Perahu Pinisi yang banyak digunakan oleh suku Bugis untuk berdagang

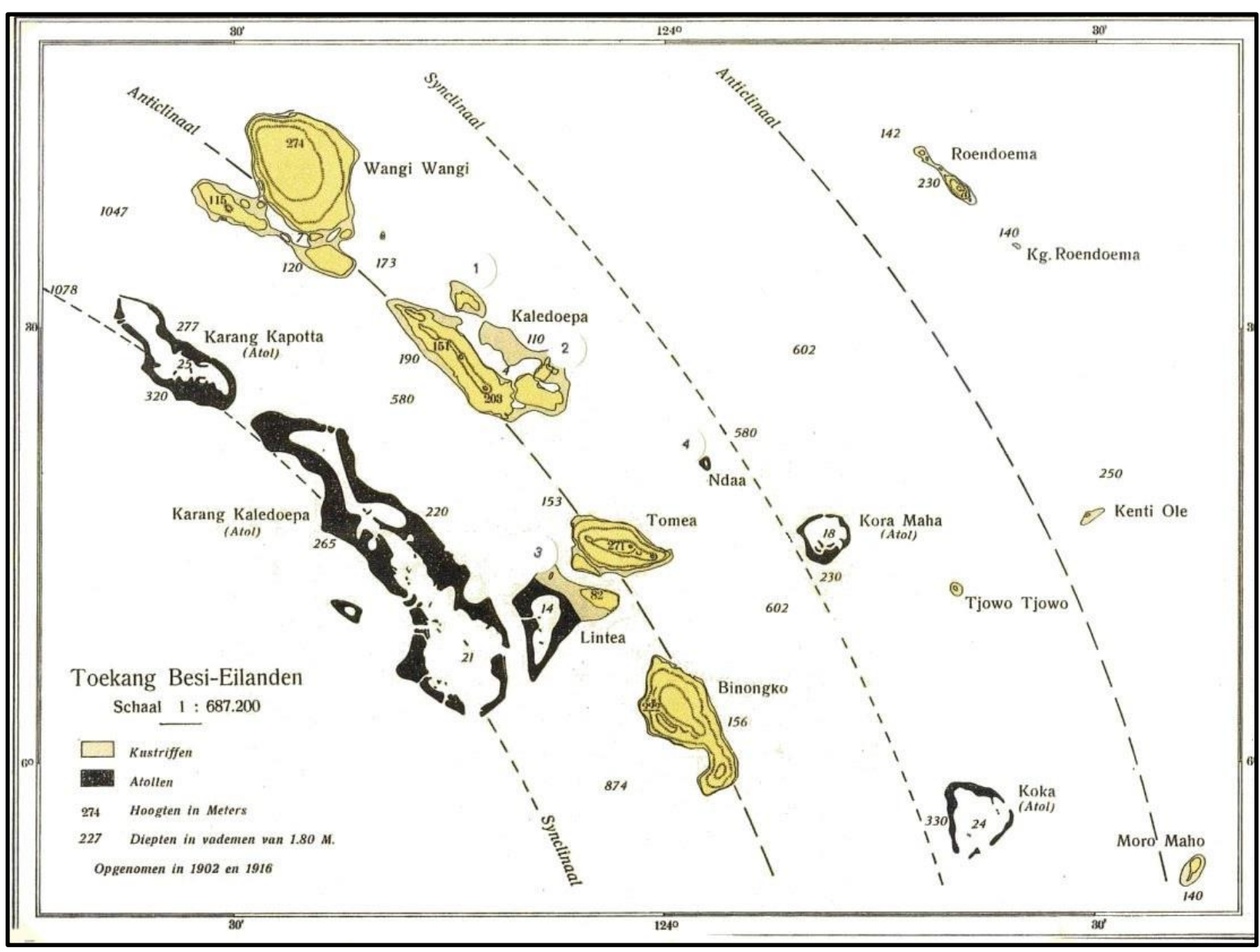

Gambar 4.1. Peta Kepulauan Wakatobi (Southon, 1995)

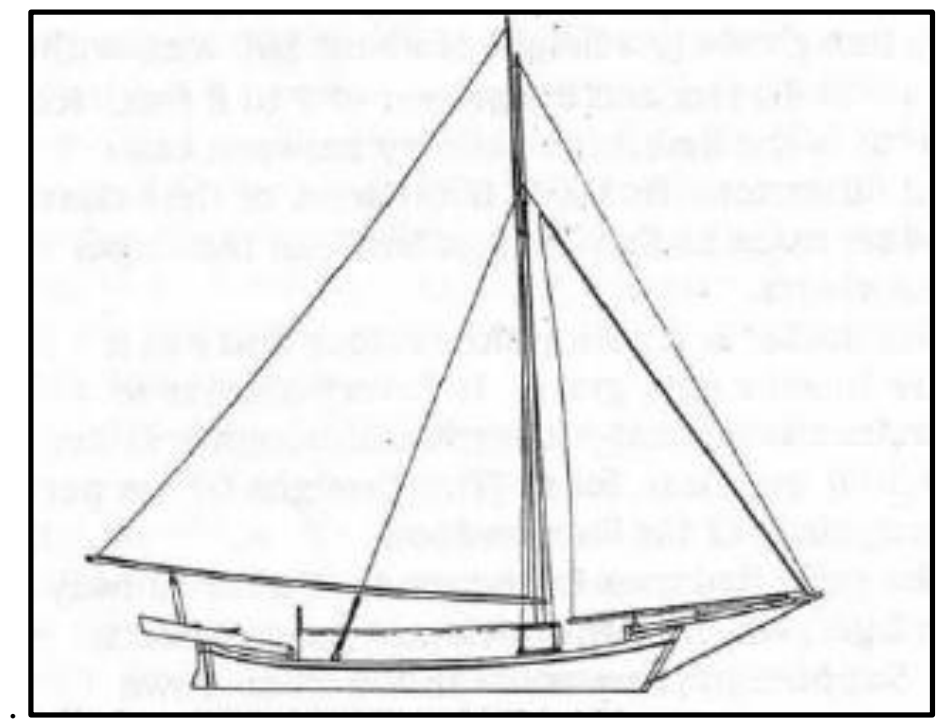

Gambar 4.2. Sketsa Perahu Lambo (Maritime Heritage Association, 1992) 
Tabel 4.1. Cuplikan Penjelajahan Pelaut Tukang Besi (Hadara, 2006)

\begin{tabular}{|c|c|c|c|}
\hline No & Tahun & Tokoh & Penjelajahan \\
\hline 1 & Abad 17 & $\begin{array}{l}\text { Orang-orang } \\
\text { Binongko }\end{array}$ & $\begin{array}{l}\text { Pelaut asal Binongko menjelajah di Kepulauan Key } \\
\text { Maluku Tenggara dan mendirikan perkampungan } \\
\text { dengan nama Kampung Tamu }\end{array}$ \\
\hline 2 & 1900 & $\begin{array}{l}\text { Sembilan pemuda } \\
\text { Binongko }\end{array}$ & $\begin{array}{l}\text { Pemuda-pemuda Binongko merantau ke Digus dan } \\
\text { Davao Mindanao di Filipina Selatan }\end{array}$ \\
\hline 3 & 1901 & $\begin{array}{l}\text { Empat orang } \\
\text { pelayar Binongko }\end{array}$ & $\begin{array}{l}\text { Pelayar Binongkko tersebut berhasil menunaikan } \\
\text { ibadah haji di Mekkah menggunakan Perahu Lambo. } \\
\text { Mereka berlabuh di Pakistan kemudian menyeberang } \\
\text { ke Mekkah melalui jalur darat. }\end{array}$ \\
\hline 4 & 1908 & $\begin{array}{l}\text { Empat orang } \\
\text { Binongko }\end{array}$ & $\begin{array}{l}\text { Orang Binongko tersebut menyeberang ke kota } \\
\text { Semorset dan Kepulauan Wessel Australia Utara. } \\
\text { Mereka telah berkeluarga dan berketerunan disana. }\end{array}$ \\
\hline 5 & 1960-an & $\begin{array}{l}\text { Pelaut asal Tomia } \\
\text { dengan nahkoda La } \\
\text { Ida }\end{array}$ & Berlabuh di Kepulauan Palau Filipina Timur \\
\hline
\end{tabular}

\subsection{Migrasi Masyarakat Buton}

Orang Buton yang mencakup seluruh wilayah kekuasaan Kesultanan Wolio adalah salah satu pengelana laut yang termasyur seperti yang telah dijelaskan diatas. Faktor pendorong yang sering digunakan untuk menjelasakan hal tersebut adalah tanah yang kurang subur dan posisi geografis yang berada di jalur pelayaran antara Indonesia Timur dan Barat (Zuhdi dkk, 2009). Indonesia Timur memiliki Maluku dan Papua yang menghasilkan hasil bumi berupa rempahrampah dan kopra, sedangkan Indonesia Barat memiliki Jawa sebagai penghasil alat-alat dan kebutuhan rumah tangga. Pelaut Buton khususnya Tukang Besi berfungsi sebagai penghubung kedua daerah ini (Hadara, 2006). Oleh karena itu, orang Buton banyak tersebar dari Barat hingga Timur Indonesia.

Letak Buton yang secara geografis strategis, ternyata juga menimbulkan permasalahan. Kepulauaan Buton seringkali menjadi sasaran bajak laut (Wafren, 2002). Perampok ini berasal dari Tobelo dan kawasan Laut Sulu. Ancaman terhadap ketentraman masyarakat Buton ternyata tidak hanya berasal dari bajak laut. Letak goegrafis wilayah ini juga mengakibatkan Buton berada diantara pengaruh politik Kerajaan Gowa dan Ternate (Zuhdi dkk, 2009). Dua 
permasalahan tersebut tentunya menjadikan penduduk Kepulauan Buton tidak aman, sehingga mereka banyak yang bermigrasi.

Migrasi yang dilakukan orang Buton memiliki pola yang dapat diklasifikasikan menjadi dua golongan (Zuhdi, 2010). Pola Ternate cenderung menjadikan orang Buton menempati kedudukan tinggi. Hal ini dikarenakan telah adanya hubungan erat antarkesultanan. Hubugan ini melibatkan masyarakat di Kulisusu Buton Utara yang mempunyai keahlian tertentu, sehingga dapat tinggal di lingkungan Keraton Ternate. Pola Ambon menempatkan mereka pada strata rendah. Orang Buton pada pola migrasi Ambon didominasi oleh masyarkaat Kepulauan Wakatobi. Orang Wakatobi yang bermigrasi ini awalnya membuka wilayah baru di Teluk Ambon dengan nama Kampuung Tomea Pekerjaan mereka didominasi oleh tukang becak, penjual toko kelontong, dan hasil bumi berskala kecil. 


\section{DAFTAR PUSTAKA}

Alimuddin, M.R. (2013). Kabar Dari Laut. Yogyakarta: Penerbit Ombak.

Alimuddin, M.R. (2013). Mengapa Kita Belum Cinta Laut. Yogyakarta: Penerbit Ombak.

Alimuddin, M.R. (2013). Orang Mandar Orang Laut. Yogyakarta: Penerbit Ombak.

Amrullah, M. (2015). Representasi Makna Simbolik Dalam Ritual Perahu Tradisional Sandeq Suku Mandar di Sulawesi Barat. Skripsi. Fakultas Ilmu Sosial Dan Ilmu Politik Universitas Hasanuddin

Badan Informasi Geospasial. (n.d.). Indonesia Memiliki 13.466 Pulau yang Terdaftar dan Berkoordinat. Diakses dari http://www.bakosurtanal.go.id/berita-surta/show/indonesiamemiliki-13-466-pulau-yang-terdaftar-dan-berkoordinat

Basri, I. (2014). Komodifikasi Ritual Duata Pada Etnik Bajo di Kabupaten Wakatobi Provinsi Sulawesi Tenggara. Tesis. Program Pascasarjana Universitas Udayana.

Bemmelen, V.R.W. (1949). The Geology of Indonesia. Nederland: Martinus Nyhoff, The Haque

Caldwell, I. (1995). Power, state and society among the pre-Islamic Bugis. Jurnal Bijdragen tot de Taal, 151 (3), 394-421.

Dahuri, R. (1996). Pengelolaan Sumberdaya Pesisir dan Lautan Secara Terpadu. Jakarta: PT. Pramadya Paramita.

Fouberg, H.E., Murphy, A.B., de Blij, H.J. (2012). Human Geography Tentth Edition. New York: John Wiley \& Sons, Inc.

Gamsir. (2014). Wajah Orang Bajo Dalam Arus Perubahan. Skripsi. Universitas Islam Negeri Sunan Kalijaga Yogyakarta.

Hadara, A. (2006). Dinamika Pelayaran Tradisional Orang Buton Kepulauan Tukang Besi. Makalah Konferensi Nasional Sejarah VIII.

Hussin, N. (2008). Pedagang Bugis dan Kuasa Eropah di Selat Malaka, 1500-1800. Jurnal Sari 26, 199-211.

Hussin, N. (2008). Pedagang Bugis dan Kuasa Eropah di Selat Malaka, 1500-1800. Jurnal Sari 26, 199-211.

Pelras, C. (1996). The Bugis. Massachusetts: Blackwell Publishers Ltd.

Suyuti, N. (2011). Orang Bajo di Tengah Perubahan. Yogyakarta: Penerbit Ombak 
Wafren, J.F. (2001). Iranun and Balangingi Globalization, Maritime Raiding and The Birth of Ethnicity. Singapore: Singapore University Press.

Wakatobi Center. (2015). Tradisi Duata dan Keberlangsungan Kehidupan Suku Bajo di Wakatobi. Diakses dari http://www.wakatobicenter.com/2015/10/tradisi-duata-dankeberlangsungan.html

Yahya, N.W. (2013). Strata Sosial Masyarakat Balanipa (Studi Atas Ketatanegaraan Islam). Skripsi. Fakultas Syariah dan Hukum UIN Alauddin Makassar.

Zuhdi, S., Pradjok, D., Setiawan, A. (2009). Diaspora Orang Buton Sebagai Faktor Integrasi bangsa. Laporan Penelitian Hibah Riset Strategis Nasional. Universitas Indonesia.

Zuhdi, S. (2010). Sejarah Buton yang Terabaikan Labu Rope Labu Wana. Jakarta: Penerbit Rajagrafindo. 